\title{
Disruption is the Norm
}

Ann Fam Med 2018;16(Suppl 1):S80. https://doi.org/10.1370/afm.2235.

The Annals of Family Medicine encourages readers to develop a learning community to improve health care and health through enhanced primary care. Participate by conducting a RADICAL journal club. RADICAL stands for Read, Ask, Discuss, Inquire, Collaborate, Act, and Learn. We encourage diverse participants to think critically about important issues affecting primary care and act on those discussions. ${ }^{1}$

\section{HOW IT WORKS}

In each issue, the Annals selects an article and provides discussion tips and questions. Take a RADICAL approach to these materials and post a summary of your conversation in our online discussion. (Open the article and click on "TRACK Discussion/ Submit a comment.") Discussion questions and information are online at: http://www.annfammed.org/site/AJC/.

\section{CURRENT SELECTION}

\section{Article for Discussion}

Mold JW, Walsh M, Chou AF, Homco JB. The alarming rate of major disruptive events in primary care practices in Oklahoma. Ann Fam Med. 2018;16(Suppl 1):S52-S57.

\section{Discussion Tips}

There is something in the human psyche that craves constancy and resists change. We tend to treat the calm patches in the sea of life as the norm. We plan for these stable periods and treat disruptions as inconvenient waystations. The article featured as the Annals Journal Club for this supplement shows that the rough waves of change are at least as usual as the glassy surface of stability, with possible implications for practices' ability to engage in quality improvement.

\section{Discussion Questions}

- What question is asked by this study and why does it matter?

- How does this study advance beyond previous research and clinical practice on this topic?
- How strong is the study design for answering the question?

- To what degree can the findings be accounted for by: o How patients were selected, excluded, or lost to follow-up?

o How the main variables were measured?

o Confounding (false attribution of causality because 2 variables discovered to be associated actually are associated with a 3rd factor)?

o Chance?

o How the findings were interpreted?

- What are the main study findings?

- What do you make of the (non-linear) association of disruption with practice size?

- What is your judgment about the transportability of the findings?

- What state and national contextual factors are important for interpreting the findings?

- What do you think of the authors' assertion that these disruptions affect practices' capacity to implement or and continue quality improvement activities?

- How might this study change your practice? Policy? Education? Research?

- Who the constituencies are for the findings, and how they might be engaged in interpreting or using the findings?

- What are the next steps in interpreting or applying the findings?

-What researchable questions remain?

\section{References}

1. Stange KC, Miller WL, McLellan LA, et al. Annals Journal Club: It's time to get RADICAL. Ann Fam Med. 2006;4(3):196-197. http:// annfammed.org/cgi/content/full/4/3/196. 